\title{
Characteristics of Metal Supported-Zeolite Catalysts for Hydrocracking of Polyethylene Terephthalat
}

\author{
Wega Trisunaryanti ${ }^{1 *}$, Triyono ${ }^{1}$, Cut Novrita Rizki ${ }^{1}$, Harwin Saptoadi ${ }^{2}$, Zainal \\ Alimuddin $^{3}$, Mochamad Syamsiro ${ }^{4}$ and Kunio Yoshikawa ${ }^{4}$, \\ ${ }^{I}$ Department of Chemistry, Faculty of Mathematics and Natural Sciences, Gadjah Mada University, Sekip \\ Utara, Yogyakarta 55281, Indonesia; \\ ${ }^{2}$ Department of Mechanical and Industrial Engineering, Faculty of Engineering, Gadjah Mada University, \\ Jalan Grafika No. 2, Yogyakarta 55281, Indonesia. \\ ${ }^{3}$ Department of Mechanical Engineering, Faculty of Engineering, University Sains Malaysia, Engineering \\ Campus, Nibong Tebal, 14300 Penang, Malaysia \\ ${ }^{4}$ Department of Environmental Science \& Technology, Faculty of Engineering, Tokyo Institute of Technology, \\ Nagatsuta-cho, Midori-ku, Yokohama 226-8502, Japan
}

\begin{abstract}
Characterization and modification of natural zeolite (ZA) produced in Sukabumi, West Java, Indonesia, as well as metal supported onto the zeolite for hydrocracking catalysts of polyethylene terephthalat (PET) have been conducted. The natural zeolite was refluxed in $\mathrm{HCl} 3 \mathrm{M}$ for 30 min., drying and heated in a microwave produced the ZAA sample. The transition metal such as $\mathrm{Cu}, \mathrm{Cr}, \mathrm{Ni}$, or Pd was loaded into the ZAA sample under reflux in methanol using salt precursor of each metal, produced the Cu/ZAA, Cr/ZAA, Ni/ZAA, and Pd/ZAA catalysts. The zeolite based samples were characterized by means of determination of acidity by vapor adsorption of $\mathrm{NH}_{3}$ and pyridine, catalyst crystalinity by $\mathrm{X}$-ray diffraction (XRD), surface area by surface area analyzer NOVA-10O0 and $\mathrm{TO}_{4}(\mathrm{~T}=\mathrm{Si}$ and $\mathrm{Al})$ site by Infra Red Spectrophotometer (IR). The PET was pyrolyzed in $350^{\circ} \mathrm{C}$ produced liquid fraction as a feed for hydrocracking process. The hydrocracking of the PET was carried out in a fixed bed reactor of stainless steel at temperature of $350{ }^{\circ} \mathrm{C}, \mathrm{H}_{2}$ flow rate of $20 \mathrm{~mL} / \mathrm{min}$., feed/catalyst ratio of 10. Liquid products of the hydrocracking were analyzed using GC and GC-MS. The characterization results showed that the Indonesian natural zeolite produced in Sukabumi consisted mainly of mordenite crystalline. The $\mathrm{HCl}$ treatment towards the natural zeolite caused dealumination, increased its acidity and surface area. Loading of $\mathrm{Ni}, \mathrm{Cu}, \mathrm{Cr}$, or Pd metal on to the zeolite did not affect the zeolite crystallinity. However, the metal loading decreased surface area of the zeolite. Products of the hydrocracking were liquid, coke, and gas fractions. The liquid products consisted mainly of gasoline fraction $\left(C_{5}-C_{12}\right)$. The highest liquid product conversion was produced by the Pd/ZAA catalyst, i.e. $34.05 \mathrm{wt}$. \%, with selectivity towards gasoline fractions was $97.99 \mathrm{wt} . \%$.
\end{abstract}

Keywords: natural zeolite, characterization, modification, hydrocracking, metal loading, polyethylene terephthalat.

\section{Introduction}

Waste plastics have caused serious environmental problems because it is not degradable. In contrast, waste plastics are regarded as cheap and abundant sources of chemicals and energy. The recycling of waste plastics into useful hydrocarbons, i.e chemicals and fuel fractions is desirable. The usual chemical recycling method used for thermoplastics such as polyethylene was combination method of pyrolysis and catalytic cracking. The pyrolysis of low-density polyethylene (LDPE) [1] as well as PVC waste plastics was carried out under the range temperature of $150-350{ }^{\circ} \mathrm{C}$ [2] and that for high-density polyethylene (HDPE) plastic was pyrolyzed in temperature range of $400-450{ }^{\circ} \mathrm{C}$ [3]. In the catalytic cracking of waste plastics, the utilization of $\mathrm{NiMo} / \mathrm{Al}_{2} \mathrm{O}_{3}$ [1] as wel as zeolite, i.e mordenite [4-5], or H-ferrierite [6], ZSM-5 [7], and mesostructure [5] catalysts produced high conversion of liquid fractions.

Zeolites play highly important roles as catalyst in catalytic cracking because it has unique properties such as high crystallinity, surface area, acidity, ion-exchanged capacity, and shape-selective character. On the other hand, there are widespread, abundant resources of natural zeolites in Indonesia. Their utilization as catalysts, however, has been little explored, in spite of the fact that their potential effectiveness may contribute to reduce industrial production costs. Synthetic zeolites were used in a wide range as catalysts. However, the synthetic zeolite was expensive and still imported by Indonesia. In spite of the fact that Indonesia have abundant natural zeolites spread out in Java, Celebes, Sumatra and Timor. Indonesian natural zeolites produced in West Java (Bayah and Cipatuja), Center of Java (Wonosari, Yogyakarta) has been known contains large portion of Mordenite. The zeolites showed better performance in crystallinity and acidity after treated with $\mathrm{HCl}$ [8-9]. 
Various methods have been developed to modify their acid properties and to improve their catalytic performance, e.g. supported of transition metals into the $\mathrm{Al}_{2} \mathrm{O}_{3}$ [1] as wel as the zeolite framework [10-11].

Based on the above consideration, the authors undertaken characterization of natural zeolite produced in Sukabumi, West Java, Indonesia, and its modifications by treating with an aqueous $\mathrm{HCl}$ solution, followed by microwave treatment. In an attempt to increase the zeolite performance as catalyst, transition metals, i.e $\mathrm{Ni}, \mathrm{Cu}$, $\mathrm{Cr}$, or Pd was supported into the zeolite framework. Their characters to hydrocrack polyethylene terephthalat (PET) were then evaluated. The results are discussed as followed.

\section{1. Treatment of Zeolite}

\section{Experimental}

Natural zeolite (ZA) produced in Sukabumi, Indonesia was ground and sieved to $<100$ mesh particles before use. About $5 \mathrm{~g}$ of natural zeolite sample in $3 \mathrm{~N} \mathrm{HCl}\left(125 \mathrm{~cm}^{3}\right)$ was heated at $90{ }^{\circ} \mathrm{C}$ for $30 \mathrm{~min}$. while magnetically stirred. After the $\mathrm{HCl}$ treatment, the sample was filtered and washed with deionized water until no chloride ion could be detected by test using $\mathrm{AgNO}_{3}$ solution, after which it was dried at $120{ }^{\circ} \mathrm{C}$ for $3 \mathrm{~h}$ and then heated in a microwave at 450 watt for 30 min. produced the ZAA sample.

\section{2. Impregnation of metal onto the zeolite}

Twenty five grams of ZAA sample was mixed with $\mathrm{Ni}\left(\mathrm{NO}_{3}\right)_{2} \cdot 6 \mathrm{H}_{2} \mathrm{O}(1.25 \mathrm{~g})$ in $200 \mathrm{~mL}$ of methanol followed by refluxing. The mixture was laid still for $5 \mathrm{~h}$, after which the solvent was evaporated. After drying at $120{ }^{\circ} \mathrm{C}$ for $3 \mathrm{~h}$, the sample was then heated in a microwave at 450 watt for $30 \mathrm{~min}$., followed by reducing under hydrogen gas stream $\left(20 \mathrm{~mL} / \mathrm{min}\right.$.) at $400{ }^{\circ} \mathrm{C}$ for $3 \mathrm{~h}$, produced the Ni/ZAA sample. The impregnation of others metal onto the zeolite was carried out under the same procedure using $\mathrm{Cr}\left(\mathrm{NO}_{3}\right)_{3} .9 \mathrm{H}_{2} \mathrm{O}(1.95 \mathrm{~g})$ produced the $\mathrm{Cr} / \mathrm{ZAA}$ sample; $\mathrm{Cu}\left(\mathrm{NO}_{3}\right)_{2} .3 \mathrm{H}_{2} \mathrm{O}(0.925 \mathrm{~g})$ produced the $\mathrm{Cu} / \mathrm{ZAA}$ sample; and $\mathrm{PdCl}_{2}(0.4 \mathrm{~g})$ produced the $\mathrm{Pd} / \mathrm{ZAA}$ sample, respectively. The chemicals used were produced by Merck.

\section{3. Catalyst Characterization}

The effect of modified treatments towards dealumination as well as acid sites in the natural zolite was analyzed by FT-IR Spectroscopy (Shimazu). Total acid site amount on zeolite samples was determined gravimetrically using ammonia and pyridine base vapour adsorption. Crystallinity changed of zeolite samples was analyzed by $\mathrm{x}$-ray diffraction (XRD)-Shimazu, surface area was determined using NOVA-1000, Quantachrome Corporation based on the BET equation, and $\mathrm{Si} / \mathrm{Al}$ ratio was analyzed by Atomic Absorption Spectrophotometer (AAS) Perkin Elmer 3110, respectively.

\section{4. Catalytic Activity Test}

Catalytic activity test was carried out in hydrocracking process of the Polyethylene terephthalat (PET). The PET was pyrolyzed in $350{ }^{\circ} \mathrm{C}$ to produce liquid fraction as a feed prior for hydrocracking process. The process was conducted in a semi flow reactor system using $\mathrm{H}_{2}$ gas at flow rate of $20 \mathrm{~mL} / \mathrm{min}$.; for $60 \mathrm{~min}$; reaction temperature $350{ }^{\circ} \mathrm{C}$, feed/catalyst weight ratio $=10$ (the feed was a PET). Thermal cracking (without catalyst) of the PET was conducted at $600{ }^{\circ} \mathrm{C}$ for $4 \mathrm{~h}$. Thermal cracking (without catalyst) of the PET was conducted at $600{ }^{\circ} \mathrm{C}$ for $4 \mathrm{~h}$. The hydrocracking products consisted of gas, liquid, coke, and residue. The liquid product was analyzed by gas chromatography (GC) and chromatography-mass spectroscopy (GCMS) SHIMADZU QP2010S. Oxidation of the used catalyst was conducted at $500{ }^{\circ} \mathrm{C}$ for $1 \mathrm{~h}$ to determine the amount of coke. The product conversion (wt.\%) was quantitatively calculated by means of \{ (weight of the product)/initial weight of the PET) $\} 100 \%$. Gas product (wt.\%) was quantitatively calculated by means of (100 coke - liquid - residue)\%. Selectivity of gasoline and diesel fractions was calculated by \{GC area of gasoline or diesel/total area of liquid product) $100 \%$.

\section{Result And Discussion}

Effect of the $\mathrm{HCl}$ treatment towards dealumination of zeolite framework was analyzed by Infra Red Spectroscopy (IR) based on the wave number of $\mathrm{TO}_{4}\left(\mathrm{~T}=\mathrm{Si}\right.$ or Al) site at $1250-950 \mathrm{~cm}^{-1}$. The result was shown in Fig. 1.

Fig. 1 showed that the acid treatment caused dealumination of the zeolite sample indicated by the shifted of the wave number from 1041.56 to $1087.85 \mathrm{~cm}^{-1}$. The successive treatment caused the increase of dealumination. The acid treatment leached $\mathrm{Al}$ framework of Indonesian natural zeolites as shown by research undertaken by Trisunaryanti et al. [7-8]. This data was in line with the result of Si/Al ratio (mol/mol) of the ZA and ZAA sample of 4.3 and 6.2.The ratio of $\mathrm{Si} / \mathrm{Al}$ increased due to the dealumination process. 


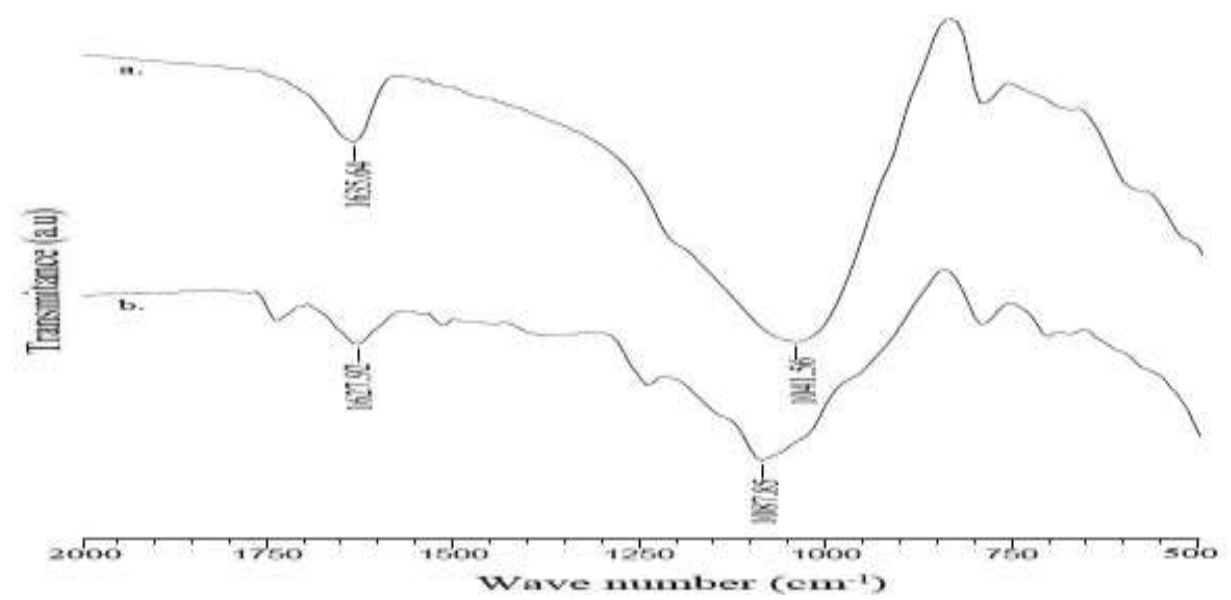

Figure 1 Infra Red Spectra of: a) ZA and b) ZAA

Total acid amount of the zeolite samples determinated by ammonia or pyridine base vapour adsorption was shown in Table 1. It was shown that the acid amount determined by ammonia was higher than that of pyridine. This phenomena could be explained by the facts that ammonia was a stronger base than that of pyridine and pyridine has bigger molecular size than ammonia thus pyridine can only adsorbed in the outer surface of the zeolite. Ammonia with smaller molecular size can be adsorbed on outer and inside the zeolite surfaces. It could also be seen that the total acid amount of the zeolite samples increased by the $\mathrm{HCl}$ treatment. Impregnation of metas onto the ZAA sample increased the ammonia acidity. On the other hand, pyridine acidity of the ZAA sample increased by loading of $\mathrm{Ni}$ or $\mathrm{Cu}$ metal, whereas the $\mathrm{Cr}$ and $\mathrm{Pd}$ did not affect the pyridine acidity of the ZAA. These results indicated that the loading of a small amount of metal onto the ZAA sample performed a new acid site (Lewis acid).

Table 1 Total acid amount of the zeolite samples

\begin{tabular}{ccc}
\hline Sample & Ammonia $(\mathrm{mmol} / \mathrm{g})$ & Pyridine $(\mathrm{mmol} / \mathrm{g})$ \\
ZA & 0,44 & 0,16 \\
ZAA & 1,76 & 0,32 \\
Cr/ZAA & 2,57 & 0,31 \\
Cu/ZAA & 2,63 & 0,68 \\
Ni/ZAA & 3,98 & 0,82 \\
Pd/ZAA & 3,58 & 0,32 \\
\hline
\end{tabular}

The infra Red spectroscopy of the ZAA sample before and after adsorption of pyridine vapour base was shown in Fig. 2. This Figure showed that the Lewis acid $\left(1627.92\right.$ and $\left.1753.93 \mathrm{~cm}^{-1}\right)$ and Bronsted acid $\left(1543.05 \mathrm{~cm}^{-1}\right)$ sites were available in the zeolite sample. This phenomenon described that the zeolite was promising to be used as acid catalyst as well as supported catalyst.

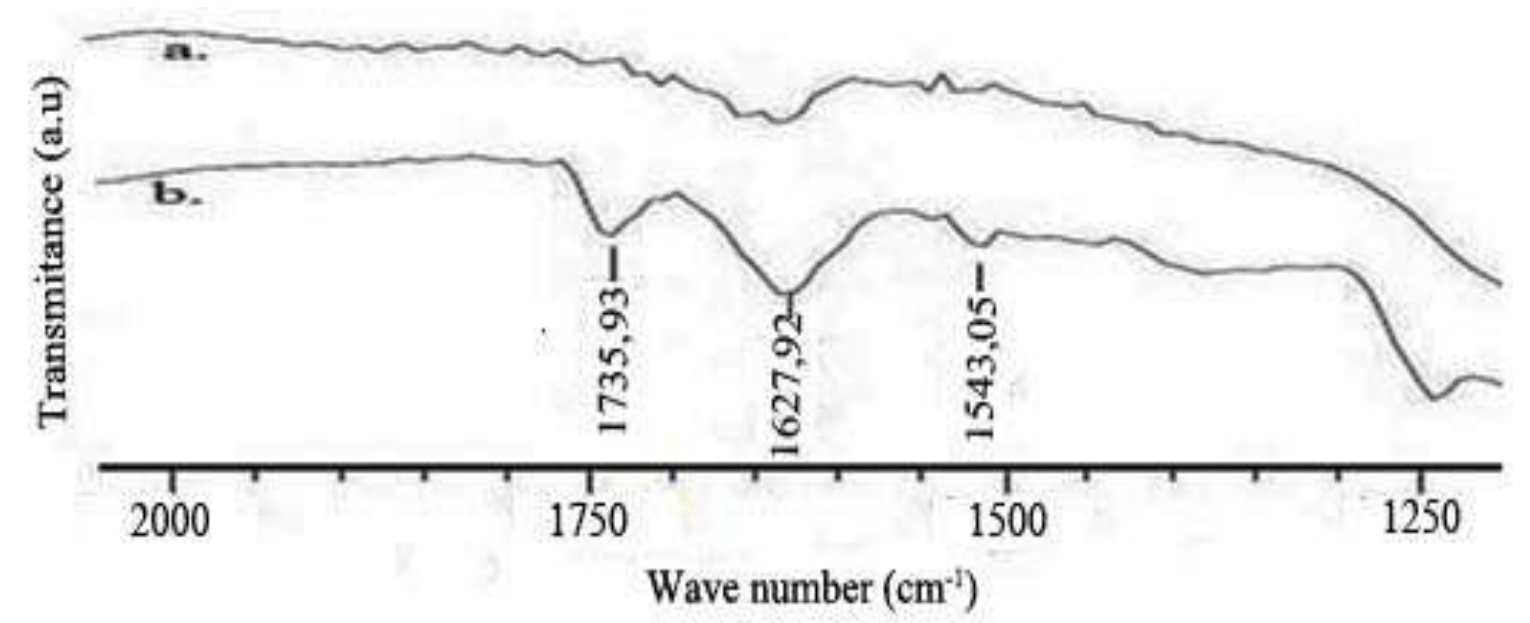

Figure 2 Infra Red Spectra of ZAA sample: a) before and b) after pyridine absorption 
Fig. 3 showed the difractograms of the zeolite samples. It was found that the natural zeolite produced in Sukabumi, West Java, Indonesia consisted mainly of the mordenite type crystalline. Treatment of $\mathrm{HCl}$ towards the zeolite as well as impregnation of transition metal on to the zeolite did not alter the zeolite crystallinity.

The BET surface area of the ZA, ZAA, Ni/ZAA, Cr/ZAA, Cu/ZAA and Pd/ZAA was 24.63, 133.75, $46.13,50.61,47.47$, and $53.89 \mathrm{~m}^{2} / \mathrm{g}$, respectively. The $\mathrm{HCl}$ activation followed by microwave treatment towards the ZA sample extremely increased its surface area. This result indicated that the activation and treatment reduced the impurity that blockage the pore mouth of the zeolite. Impregnation of metal onto the ZAA framework decreased its surface area. This phenomena were taken place may be caused by the non homogeneous distribution of metal in the ZAA surface. Some of the metal atoms may block the pore mouth of the zeolite.

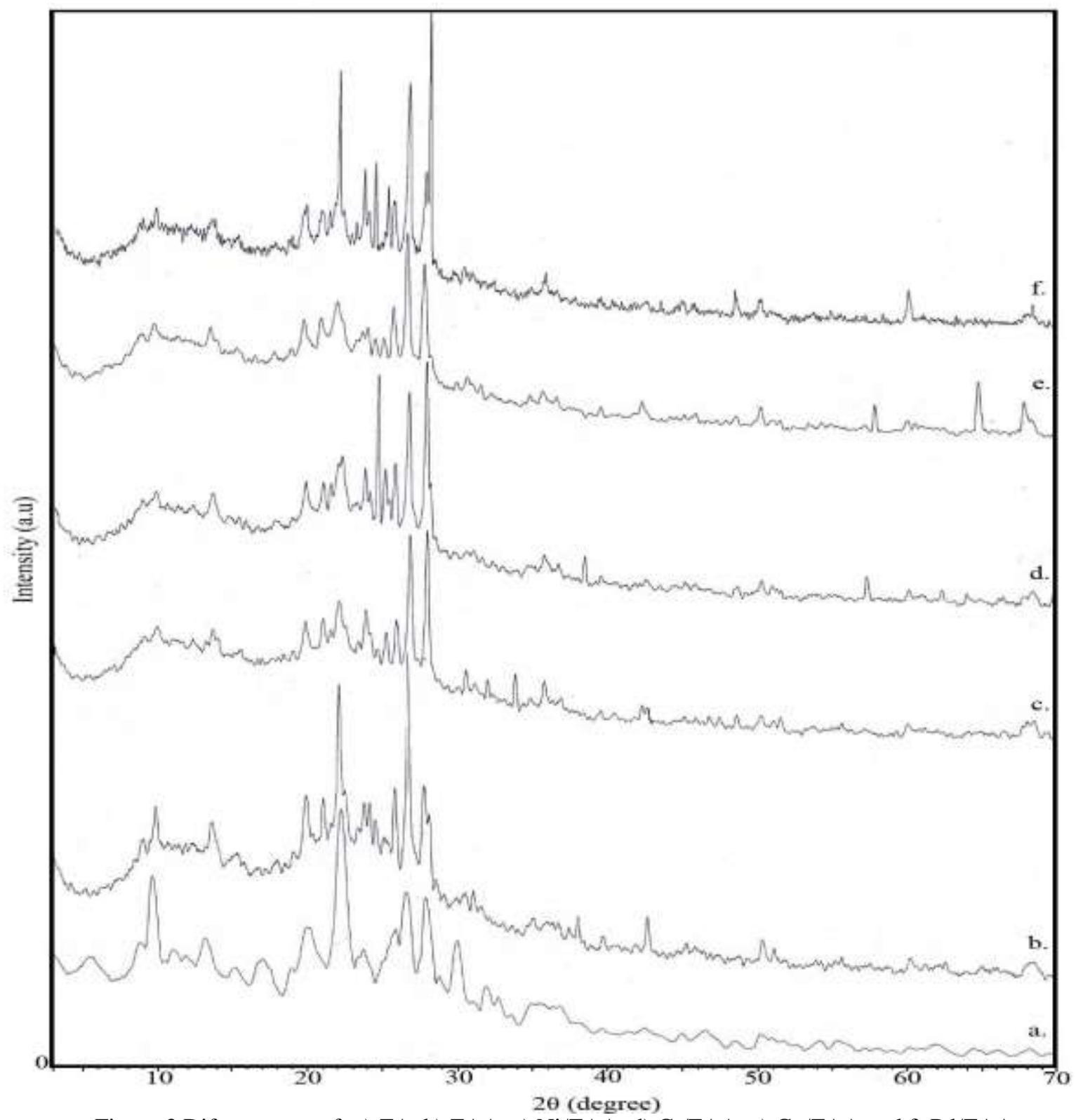

Figure 3 Difractogram of: a) ZA, b) ZAA, c) Ni/ZAA, d) Cr/ZAA, e) Cu/ZAA and f) Pd/ZAA

Table 2 showed the activity of the zeolite catalysts on hydrocracking of the pyrolized PET. It was seen that the thermal process produced the highest number of gas fraction, whereas using zeolites as well as metal supported-zeolite catalysts showed a higher amount of the liquid product. This condition can be described by the fact that the thermal cracking proceed via the radical mechanism. The zeolite based catalyst consisted of acid sites that hydrocracked the PET feed via the carbonium ion intermediate to produce branched alkane and $\mathrm{n}$ alkene in the range of liquid hydrocarbons with carbon number range between $C_{7}-C_{15}$ [12]. The highest conversion of liquid product was performed using Pd/ZAA catalyst. 
Tabel 2 Product distribution of hydrocracking of pyrolized PET

\begin{tabular}{|c|c|c|c|c|}
\hline \multirow{2}{*}{ Catalyst } & \multicolumn{4}{|c|}{ Product distribution (wt. \%) } \\
\hline & Liquid & Coke & Residue & Gas \\
\hline Thermal $^{\text {a) }}$ & 21,90 & - & 0,09 & 78,01 \\
\hline $\mathrm{ZA}^{\mathrm{b})}$ & 22,95 & 2,64 & 1,77 & 72,64 \\
\hline $\mathrm{ZAA}^{\mathrm{b})}$ & 24,74 & 2,65 & 2,18 & 70,43 \\
\hline $\mathrm{Cr} / \mathrm{ZAA}^{\mathrm{b})}$ & 32,03 & 2,85 & 2,39 & 62,73 \\
\hline $\mathrm{Cu} / \mathrm{ZAA}^{\mathrm{b})}$ & 30,85 & 3,76 & 3,03 & 62,36 \\
\hline $\mathrm{Ni} / \mathrm{ZAA}^{\mathrm{b})}$ & 29,81 & 3,35 & 2,27 & 64,57 \\
\hline $\mathrm{Pd} / \mathrm{ZAA}^{\mathrm{b})}$ & 34,05 & 1,47 & 12,28 & 52,2 \\
\hline
\end{tabular}

Note: a) carried out at $600{ }^{\circ} \mathrm{C}$ within $4 \mathrm{~h}$; b) carried out at $350{ }^{\circ} \mathrm{C}$ within $60 \mathrm{~min}$.

Table 3 showed the product distribution of the liquid fraction that consisted of gasoline $\left(\mathrm{C}_{5}-\mathrm{C}_{12}\right)$ fraction in retention time range of $0-10 \mathrm{~min}$. and that of diesel $\left(\mathrm{C}_{13}-\mathrm{C}_{20}\right)$ fraction in the range of retention time of $>10 \mathrm{~min}$. The gasoline fraction was predominant for thermal and catalytic cracking conditions. This result was consistent with the result showed by Aguado, et al [4]. The utilization of metal supported-zeolite catalysts increased the gasoline product. The highest portion of gasoline fraction was shown by Pd/ZAA catalyst (97.99 wt. \%) similar to that of Cr/ZAA catalyst (97.45 wt. \%). The data was supported by chromatogram of the product showed in Fig. 4.

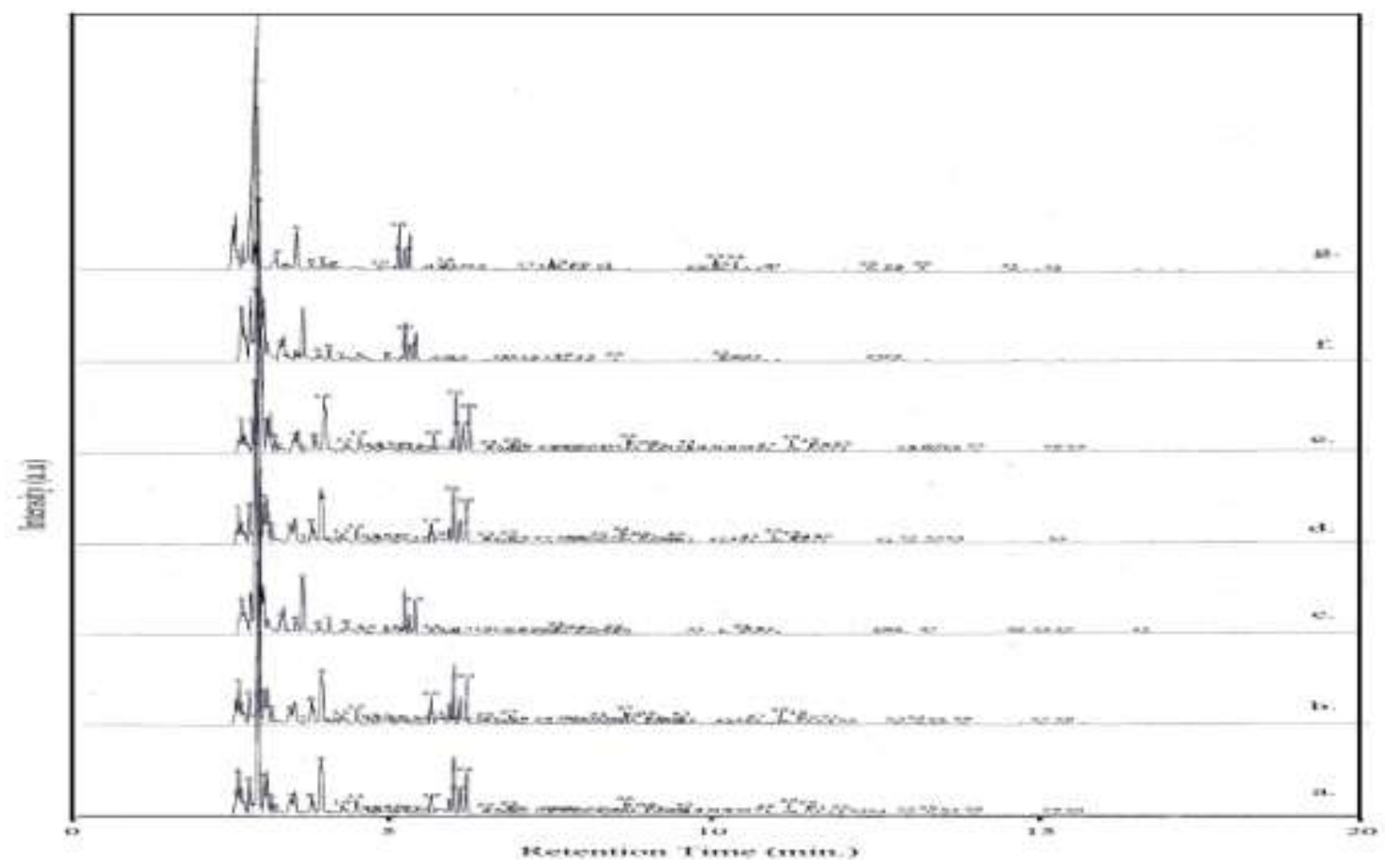

Figure 4 Difractograms of the hydrocracking product of PET using: a) ZA, b) ZAA, c) Ni/ZAA, d) Cr/ZAA, e) $\mathrm{Cu} / \mathrm{ZAA}, \mathrm{f}) \mathrm{Pd} / \mathrm{ZAA}$ catalyst, and g) thermal

Table 3 Product distribution of liquid fraction

\begin{tabular}{ccc}
\hline \multirow{2}{*}{ Catalyst } & \multicolumn{2}{c}{ Product distribution (wt. \%) } \\
\cline { 2 - 3 } & Gasoline Fraction & Diesel Fraction \\
\hline Thermal $^{\text {a) }}$ & 85,49 & 14,51 \\
ZA $^{\text {b) }}$ & 90,52 & 9,48 \\
ZAA $^{\text {b) }}$ & 91,05 & 8,95 \\
$\mathrm{Cr} / \mathrm{ZAA}^{\mathrm{b})}$ & 97,45 & 2,55 \\
$\mathrm{Cu} / \mathrm{ZAA}^{\mathrm{b})}$ & 93,93 & 6,07 \\
$\mathrm{Ni} / \mathrm{ZAA}^{\mathrm{b})}$ & 92,30 & 7,70 \\
$\mathrm{Pd} / \mathrm{ZAA}^{\mathrm{b})}$ & 97,99 & 2,01 \\
\hline
\end{tabular}

Note: a) carried out at $600{ }^{\circ} \mathrm{C}$ within $4 \mathrm{~h}$; b) carried out at $350{ }^{\circ} \mathrm{C}$ within $60 \mathrm{~min}$. 
The thermal cracking was carried out at $600^{\circ} \mathrm{C}$ that gave initial liquid product after $2 \mathrm{~h}$ run, while that of the catalytic hydrocracking was conducted at $350{ }^{\circ} \mathrm{C}$ produced initial liquid product after 30 min. run. These conditions indicated that the catalytic hydrocracking was more effective than that of the thermal cracking in order to produce the lighter liquid fractions from the PET feed.

\section{Conclusion}

Characterization and modifications of Indonesian natural zeolite produced in Sukabumi, West Java, have been carried out. Loading of a small amount of transition metal onto the activated zeolite was also performed to evaluate their characteristics in hydrocracking of the PET. The results were concluded herein.

The characterization results indicated that the Indonesian natural zeolite produced in Sukabumi consisted mainly of mordenite type crystalline. The $\mathrm{HCl}$ treatment towards the natural zeolite caused dealumination, increased its acidity and surface area. Loading of $\mathrm{Ni}, \mathrm{Cu}, \mathrm{Cr}$, or Pd metal on to the zeolite did not affect the zeolite crystallinity. However, the metal loading decreased surface area of the zeolite. The hydrocracking products of PET were liquid, coke, and gas fractions. The liquid product consisted mainly of gasoline fraction $\left(\mathrm{C}_{5}-\mathrm{C}_{12}\right)$. The highest liquid product was performed by the Pd/ZAA catalyst, i.e. 34.05 wt. \%, with selectivity towards the gasoline fractions was 97.99 wt. \%.

\section{Acknowledgements}

The authors thank The JICA/AUN/SEED-Net for the financial support under The CRI (Collaborative Research with Industry) Program.

\section{References}

[1] P. Shivakumar and K. Anbarasu, Catalytic Pyrolysis of Dairy Industrial Waste LDPE Film Into Fuel, Intern. J. Chem. Res. 3 (2012) $52-55$.

[2] M.F. Ali and M.N. Siddiqui, Thermal and catalytic decomposition behavior of PVC mixed plastic waste with petroleum residue, J. Anal. Appl. Pyrolysis 74 (2005) $282-289$.

[3] S. Kumar and R.K. Singh, Recovery of Hydrocarbon Liquid From waste High Density Polyethilene By Thermal Pyrolisi, 28 (2011) $659-667$.

[4] J. Aguado, D.P. Serrano, J.M. Escola, and A. Peral, Catalytic Cracking of Polyethilene Over Zeolite Mordenite With Enhanced Textural Properties, J. Anal. Appl. Pyrolysis 85 (2009) 352 - 358

[5] A. Peral, J. Aguado, D.P. Serrano, J.M. Escolla, Catalytic cracking of polyethylene over zeolite mordenite with enhanced textural properties, J. Anal. Appl. Pyrolysis 85 (2009) 352-358.

[6] A. Bonila, D. Baudouin, and J. Perez-Ramirez, Desilication of ferrierite zeolite for porosity generation and improved effectiveness in polyethylene pyrolysis, Journal of Catalysis 265 (2009) 170-180.

[7] A. López, I. de Marco, B.M. Caballero, M.F. Laresgoiti , A. Adrados, A. Aranzabal, 2011, Catalytic pyrolysis of plastic wastes with two different types of catalysts: ZSM-5 zeolite and Red Mud, Applied Catalysis B: Environmental 104 (2011) $211-219$.

[8] W. Trisunaryanti, R. Shiba, M. Miura, M. Nomura, N. Nishiyama, M. Matsukata, Characterization and Modification of Indonesian Natural Zeolites and Their Properties for Hydrocracking of a Paraffin, J. Jpn. Petr.Inst. 1 (1996) 20-25.

[9] W. Trisunaryanti, A. Syoufyan, S. Purwono, I.Izul Fallah, Padi, P., The effect of hydrochloric acid solution treatment towards characters of Indonesian natural zeolite, Proceeding of The 2nd International Conference On Chemical Sciences, Yogyakarta, 2010.

[10] W. Trisunaryanti, Triyono, Purwono, S., and K. Dewi, Characteristicsof Metals Supported-Zeolites Catalysts On Steam Reforming of Bioethanol, J. Materiala Science and Engineering, 5 (2011) 239-246.

[11] J.M. Escola, J. Aguado, D.P. Serrano, A. Garciaa, A. Peral, L. Briones, R. Calvo, E. Fernandez, 2011, Catalytic hydroreforming of the polyethylene thermal cracking oil over Ni supported hierarchical zeolites and mesostructured aluminosilicates, Applied Catalysis B: Environmental 106 (2011) 405-415

[12] S.T. Sie, Acid-catalyzed cracking of paraffinic hydrocarbons. 3. Evidence for the protonated cyclopropane mechanism from hydrocracking/hydroisomerization experiments, Ind. Eng. Chem. Res. 31 (2003) 1881-1889. 